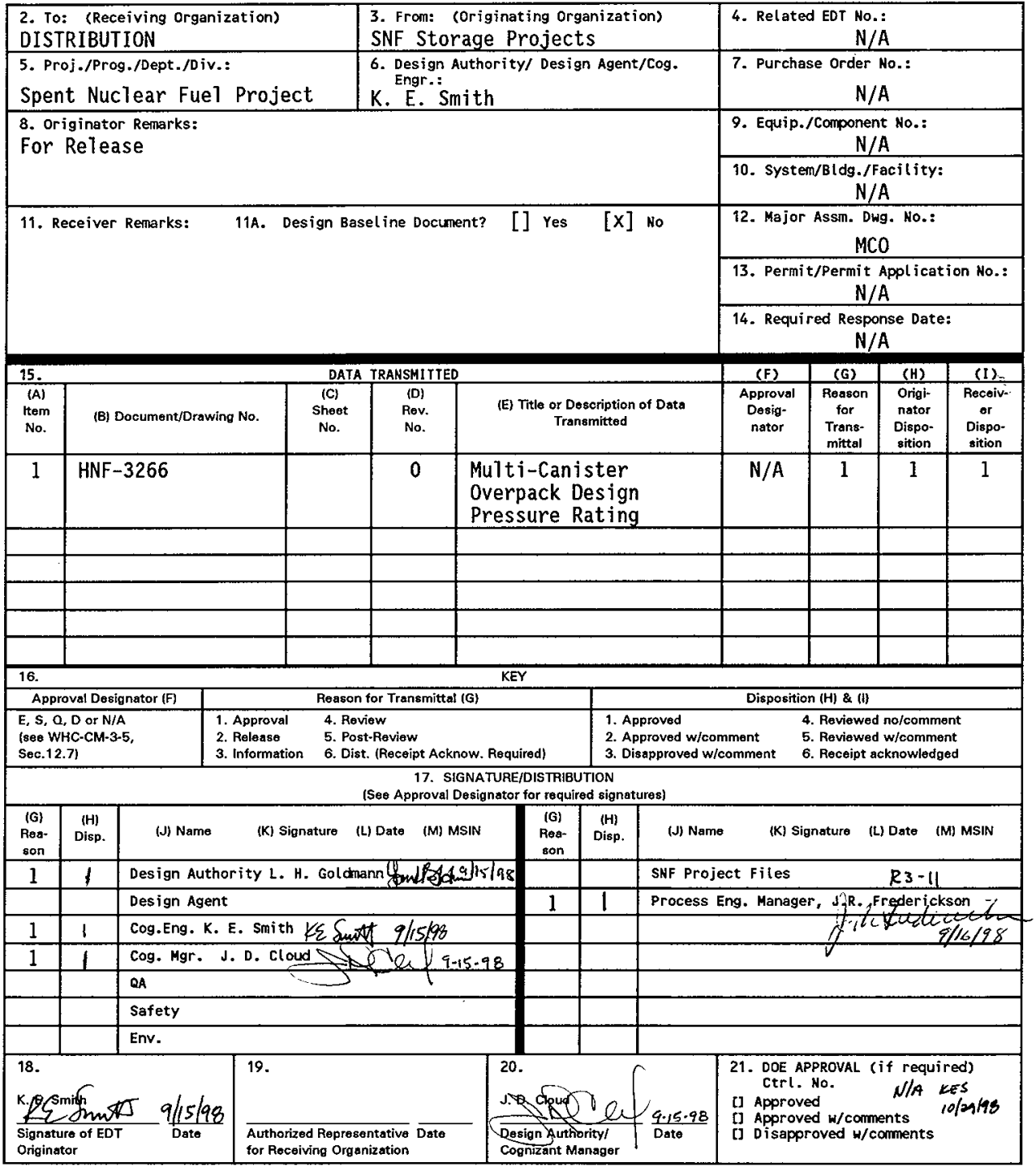

BD-7400-172-2 (05/96) GEF097 


\title{
Multi-Canister Overpack Design Pressure Rating
}

\author{
K. E. Smith
}

DE\&S Hanford, Inc., Richland, WA 99352

U.S. Department of Energy Contract DE-AC06-96RL13200

$\begin{array}{lll}\text { EDT/ECN: } & 625078 & \text { UC: } 600 \\ \text { Org Code: } & 2 \text { T340 } & \text { Charge Code: LE004 } \\ \text { B\&R Code: } & \text { EW7040000 } & \text { Total Pages: } 4\end{array}$

Key Words: MCO, Spent Fue1, Design Pressure, Packaging, Container, Issue

Abstract: The SNF project was directed to increase the MCO pressure rating by the U.S. Department of Energy, Richland Operations Office (RL) unless the action was shown to be cost prohibitive. This guidance was driven by RL's assessment that there was a need to improve margin and reduce risks associated with assumptions supporting the bounding pressure calculation for the MCO Sealing Strategy. Although more recent pressure analyses show a bounding MCO pressure of $50 \mathrm{psig}$, RL still considers it prudent to retain the pressure margin the 450 psig rating provides. This rating creates a real, clearly definable margin and significantly reduces the risk that the safety basis will be challenged.

TRADEMARK DISCLAIMER. Reference herein to any specific comercial product, process, or service by trade name, tradenark, manufacturer, or otherwise, does not necessarily constitute or imply its endorsement, recommendation, or favoring by the United States Government or any agency thereof or its contractors or subcontractors.

Printed in the United States of America. To obtain copies of this document, contact: Document Control Services, P.O. Box 950, Mailstop H6-08, Richland WA 99352, Phone (509) 372-2420; Fax (509) 376-4989.
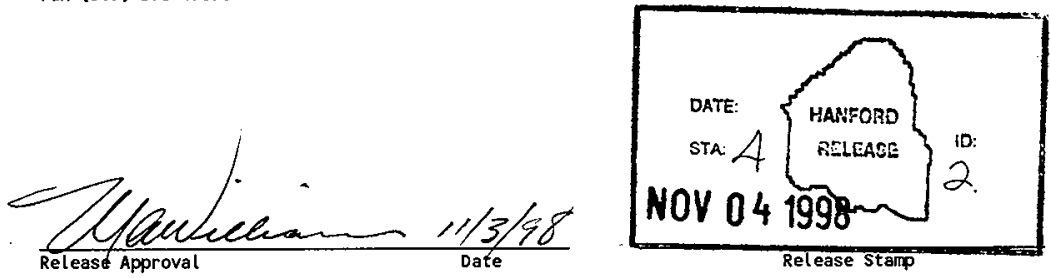

\section{Approved for Public Release}




\section{Issue Closure Package}

Issue: $\quad$ MCO Design Pressure Rating

Lead:

K. E. Smith

MCO Implementation

Manager, DE\&S Hanford

\section{Approva1s:}

Chief Engineer:

A. M. Segrest DE\&S Hanford

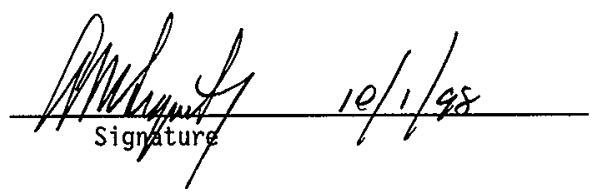

Technical Operations:

J. A. Swenson

Manager

DE\&S Hanford

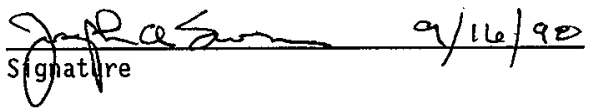

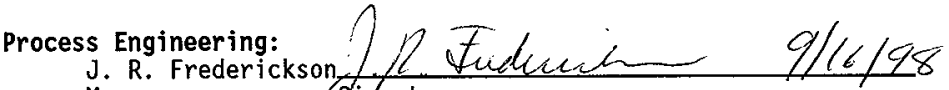

Manager

DE\&S Hanford

Nuclear Safety:

Robert G. Morgan

Manager

DE\&S Hanford

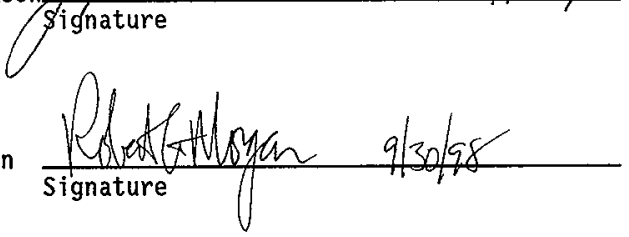

MCO Design Authority: L. H. Goldmann DE\&S Hanford
Guislifoldion alisior
Signature 
HNF-3266, Rev.0

MULTI-CANISTER OVERPACK

DESIGN PRESSURE RATING

\section{Introduction}

The MCO Sealing Strategy increased the MCO design pressure from 150 psig to $450 \mathrm{psig}$. The basis for selection of the $450 \mathrm{psig}$ pressure rating is documented in Reference 1.

\section{Discussion}

The SNF project was directed to increase the MCO pressure rating by the U. S. Department of Energy, Richland Operations Office (RL) unless this action was shown to be cost prohibitive. This guidance was driven by RL's assessment that there was a need to improve margin and reduce risks associated with assumptions supporting the bounding pressure calculation for the MCO Sealing Strategy. Review of the MCO design indicated that through minimal modifications the MCO pressure rating could be increased from 150 to $450 \mathrm{psig}$, which is within the strength of the MCO main body (0.5" wal1). Subsequent refined calculations and fuel characterization have provided greater margin and confidence in the bounding pressure analysis. However, RL still considers it prudent to retain the pressure margin the $450 \mathrm{psig}$ provides.

The initial bounding $\left(10^{-6}\right.$ probability) pressure analysis for the MCO Sealing Strategy was provided in HNF-1523, Rev. 0 in November, 1997. This was a formaliy released and peer reviewed document. It calculated a bounding pressure of $133 \mathrm{psig}$ based on 1 imited characterization data and assumptions of fuel cleaning efficiencies, including $70 \%$ of aluminum hydroxide coatings. The proximity of this bounding pressure to the MCO pressure rating of $150 \mathrm{psig}$, and challenges to the analysis due to limited characterization data and bases for supporting assumptions prompted RL to request an increase in MCO pressure margin. Subsequent pressure calculations performed in HNF-SD-SNF-TI-040, Rev. 2 provide a refined model which better accounts for bound water behavior and does not require aluminum hydroxide coating cleaning. It calculates a bounding pressure of $50 \mathrm{psig.} \mathrm{Characterization} \mathrm{data} \mathrm{supporting} \mathrm{this} \mathrm{analysis} \mathrm{includes}$ whole element drying tests, particulate and coating measurements, and uranium hydrate TGAs. This analysis demonstrates significant pressure margin for processing and storage of MCOs.

The original cost estimate to increase the MCO pressure rating was about $\$ 3 M$ in MCO fabrication costs, mostly due to the addition of higher strength collar material. Subsequent refinements in the MCO pressure rating strategy resulted in a change back to the $150 \mathrm{psig}$ rating for the mechanical closure only, while retaining the 450 psig rating once the cover cap is welded in place. This change permitted the return to a lower cost material for the collar (304L/304 
HNF-3266, Rev. 0

stainless stee1). Refer to HNF-3267 for a discussion of the dual pressure rating approach.

\section{Conclusion}

The SNF Project endorses the higher MCO pressure rating and continues to retain the $450 \mathrm{psig}$ pressure rating requirement on the final welded $M C O$ with concurrence from $\mathrm{RL}$. This rating creates a real, clearly definable margin and significantly reduces the risk that the safety basis will be challenged. It also reduces the necessity for pressure monitoring of the MCOs during interim storage.

\section{Reference}

1. Interoffice Correspondence, J.R. Frederickson to J.D. Cloud, MCO 450 PSIG Pressure Rating Basis, JFR-98-016, dated Ju7y 28, 1998 


\section{DISTRIBUTION COVERSHEET}

Subject: MCO ISSUE PAPERS PER ATTACHED DISTRIBUTION INDEX

\section{DISTRIBUTION}

Spent Nuclear Fuel Project

W. C. Alaconis

G. D. Bazinet

J. D. Cloud

D. R. Duncan

J. R. Frederickson

L. J. Garvin

L. H. Goldmann

A. R. Hollins, Jr.

C. R. Hoover

J. J. Irwin

B. D. Lorenz

C. R. Miska

R. G. Morgan

R.P. Omberg

A. M. Segrest

R. A. Sexton

K. E. Smith

J. A. Swenson

N. H. Williams

Project File

U.S. Department of Energy

C. B. Loftis

S7-41
S7-41

S7-41

S7-41

$X$

$X$

$X$

$\mathrm{X}$

$\mathrm{X}$

$\mathrm{X}$

$\mathrm{X}$

$\mathrm{X}$

$\mathrm{X}$

$\mathrm{X}$

$\mathrm{X}$

$\mathrm{X}$

$\mathrm{X}$

$\mathrm{X}$

$\mathrm{X}$

$\mathrm{X}$

$\mathrm{X}$

$\mathrm{X}$

$\mathrm{X}$

$x$

R3-11

R3-11

$X$
$X$
$X$
$X$ 


\section{DISTRIBUTION INDEX}

The Multi-Canister Overpack Issue papers listed below are being distributed as a package to facilitate future reference and use by SNF Project personnel. The following issue papers are attached:

1. HNF-2876, Oxygen Gettering Issue Closure Package

2. HNF-3265, MCO Number of Shield Plug Ports

3. HNF-3399, MCO Necessity of the Rupture Disk

4. HNF-3267, MCO Dual Pressure Rating

5. HNF-3293, MCO Ultrasonic Examination of Closure Weld

6. HNF-3354, MCO Monitoring Issue Closure Package and HNF-3312, MCO Monitoring Activity Description

7. HNF-3292, MCO Sealing Configuration

8. HNF-3266, MCO Design Pressure Rating

9. HNF-3255, ASME Code Requirements for MCO Design and Fabrication

10. HNF-3398, MCO Inservice Inspection and Maintenance

11. HNF-3420, MCO Internal HEPA Filters

12. HNF-3036, Low Reactive Surface Area Issue Closure Package

13. HNF-3270, MCO Pressure Testing 